Original Research

\title{
Contamination of Trace Elements in River Ecosystem and Source Apportionment Based on Their Relationship with Landscape Patterns
}

\author{
Zhenglei Xie $^{1}$, Yinghui Jiang ${ }^{2}$, Hua Zhang ${ }^{3}$, Zaifeng Wang ${ }^{1}$, Ye Chen ${ }^{1 *}$ \\ ${ }^{1}$ College of Marine Science and Engineering, Nanjing Normal University, Nanjing 210023, P. R. China \\ ${ }^{2}$ State Key Laboratory of Estuarine and Coastal Research (East China Normal University) Shanghai 200241, P.R. China \\ ${ }^{3}$ Key Laboratory of Poyang Lake Wetland \& Watershed Research, Ministry of Education \\ (Jiangxi Normal University) Nanchang 330022, P.R. China
}

Received: 20 August 2020

Accepted: 16 November 2020

\begin{abstract}
Complex configuration of landscape types on different spatial scales and different slopes, such as entire basin and buffer zones, is a significant issue that affects contamination of trace elements in river ecosystem. Water and sediment samples were collected and analyzed to determine the concentration and spatial distribution of trace elements throughout various topographies and landscape types. The result demonstrated that landscape percentages (agricultural land, forest land, grassland, and built-up) would greatly affect concentration of trace elements in river, agricultural land and built-up percentage demonstrate significant positive correlation with concentration of trace elements. While forest land percentage appeared significant negative correlation with concentration of trace elements, but significant positive correlation areas are located on lower steepness slope and buffer zones with elevations of 0-500 $\mathrm{m}$. As average slope steepness increases, more significant positive correlation exists between built-up percentage and trace elements concentration in river. Mining activities are a major potential source because the landscape types of mining land area in the upstream of the river are built-up on high steepness slope, and the relationships of built-up percentage in entire sub-basin with concentration of trace elements are more significant than that in river buffer zones.
\end{abstract}

Keywords: trace elements, landscape patterns, buffer zone, topographic characteristics, multiple spatial scales, Le'an River

*e-mail: 76010@njnu.edu.cn 


\section{Introduction}

Trace elements are a vital kind of contaminants in environments resulting from human activities [1-2]. Riparian zone of trace element contamination is an effective sink because these contaminants are produced from terrestrial and aquatic ecosystems [3-5]. Trace elements concentration in aquatic ecosystems can easily transform into human food chain and threaten human well-being [6]. Combined natural process and anthropogenic activities would contribute to generation of these contaminants and their discharge into the environments via rivers and others [7]. Sediments as a useful pool of trace elements pollution in aquatic environments and would give a powerful indicator to address geochemical interactions, source signatures, and risk states of trace elements [8]. Trace elements stored in sediment have potential threats to ecosystems through bio-accumulation processes [9]. Thus, quantification of distribution, potential ecological risk of trace elements, and determination of their sources are essential for the management of river environments [10].

Landscape changes reflect anthropogenic activities, and significantly affect river pollutant loads [11-13]. The continuously increasing areas in farmland and imperious cover have been regarded as one of the greatest influential factors for the sink of trace elements [14-16]. The investigation of landscape pattern has become a hot spot to clarify the influences of landscape patterns changes upon water quality [17]. Trace metals in ecosystems would be influenced by landscape pattern [18]. The relationship between landscape pattern and trace element concentrations in river ecosystems on different tempo-spatial scales exhibits obvious differences. Nowadays, the research has focused on either landscape patterns or trace elements concentration in water and sediments [19-21]. Multiple spatial scales in entire basin or buffer zone have been used to address the relationships between landscape types and water quality [22]. Different slopes are crucial spatial factors that detect the relationships between landscape types and water quality in water ecosystems. Yu et al. (2016) found that landscape types on various slopes are helpful to identify the relationship between landscape patterns and water quality [23]. However, we still lack the information on the effects of different topographic characteristics upon the relationship between the concentration of trace elements and landscape patterns. However, the trace elements concentration relationship between different landscape types on multiple scales (sub-basin, river buffer and different slopes) and multiple agents (water and sediments) remain unclear.

With the Dexing Copper Mine development in upstream of the Le'an River basin of southeast China, significant amounts of toxic trace elements are likely to be deposit downstream, which ultimately deteriorate the water quality, leading to more and more sediments. However, the distribution of trace elements in surface water of the Le'an River Basin has rarely been investigated. Different landscape types on different steepness slopes may unveil detailed relationship with the water quality, and therefore, the land topography can be a key factor specifying the relationship between landscape patterns and river contamination [23]. Due to their close relationship with landscape patterns, streams at low elevation are highly vulnerable to land-disturbing activities [24]. Protecting aquatic ecosystems from trace elements pollution requires deep understanding the source of river contaminates both spatial scale and different landscape patterns. The goals of this study are to: (1) clarify the distribution of trace elements in various landscape types; (2) estimate trace element contaminations and their ecological risks in water and sediments; and (3) detect the sources of trace elements with multiple statistical approaches and landscape pattern analysis.

\section{Material and Methods}

\section{Study Area}

The Le'an River, located in northeastern Jiangxi Province, China, flows through Wuyuan County, Dexing County, Leping County, and Poyang County, before entering into Poyang Lake. With a permanent residents of 3 million, the river's basin covers appropriately 8,989 $\mathrm{km}^{2}$. The local climate is a variety of the subtropical monsoon climate type and features a moderate temperature difference between summer and winter. Its mean annual runoff is 9.94 billion $\mathrm{m}^{3}$. Dexing County is a famous nonferrous metal mineral development zone in China and has been extensively exploited for decades. Dexing Copper Mine is the largest open-cast mine in Asia, and $\mathrm{Pb}-\mathrm{Zn}$ mine is located downstream of the Jishui River (the most important tributary of the Le'an River and adjacent to Dexing County).

\section{Sample Collection and Chemical Analysis}

Water and sediment samples were collected at 24 sites along the Le'an River. A total of 24 surface sediment samples and 93 surface water samples were taken in May, August, October and December, 2016. Fig. 1 shows the locations of sampling sites, including three sites upstream (S1 S3), twelve sites mid-stream (S4 S13), and eight sites downstream (S14 S24). At the upstream location, sediments in river were sampled on rocks because the riverbed is almost fully covered by rocks. Surface water between approximately the depth of $0.5 \mathrm{~cm}$ and $2 \mathrm{~cm}$ was collected at all sites. At each sample site, five or more subsamples were collected from topsoil. At the mid-stream sites, five or more subsamples were collected using Van Veen Grab Sampler at depths between $0-5 \mathrm{~cm}$. After sampling, these subsamples were thoroughly mixed to form a sample composition which is sealed in clean polyethylene bags, placed in a cooler place at $4^{\circ} \mathrm{C}$, and then delivered to the laboratory 


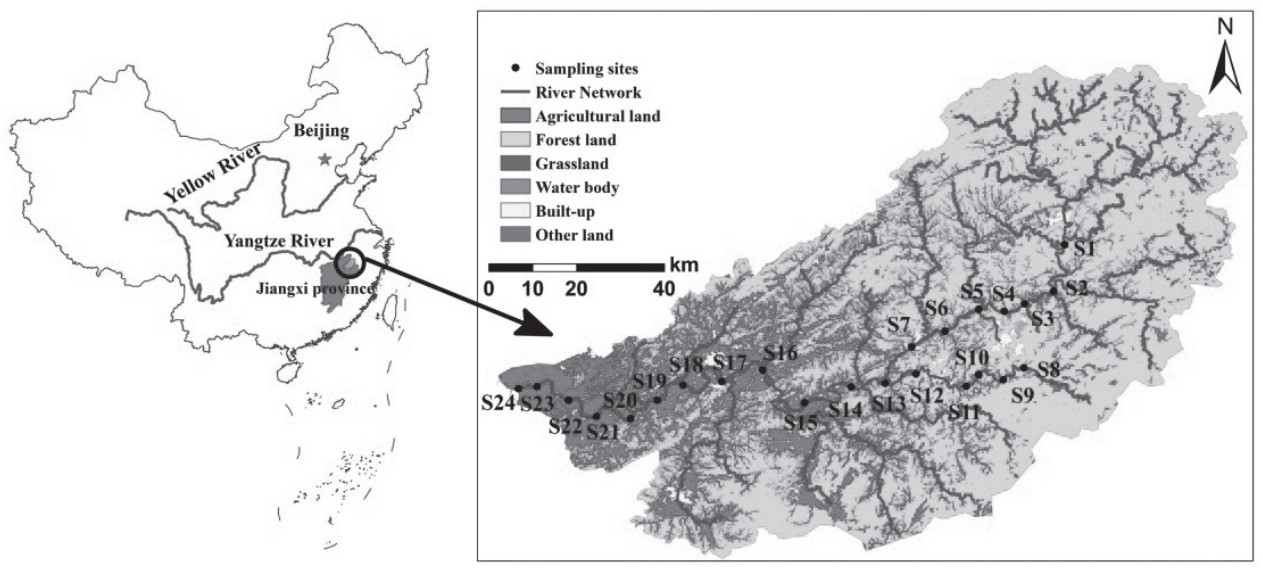

Fig. 1. Samples location in the study area.

immediately for further analysis. The sediment samples were air-dried under common temperature and filtered through a $2 \mathrm{~mm}$ nylon sieve to remove plant roots, debris, glasses, and other materials.

Total metal concentrations in sediments were measured using an established method. Specifically, 20-30 mg of the air-dried, ground sample was weighed and dissolved in $15 \mathrm{~mL}$ Teflon tubes, then moisturized with 2 or 3 drops of Milli-Q water $(18.2 \mathrm{M} \Omega \mathrm{cm})$. Then, $1 \mathrm{~mL}$ of $\mathrm{HNO}_{3}$ and $1 \mathrm{~mL}$ of $\mathrm{HF}$ were added into the samples, which were placed on a hot plate and evaporated near dryness at $150^{\circ} \mathrm{C}$. The residue was dissolved in $1 \mathrm{~mL}$ of $\mathrm{HNO}_{3}$ and $1 \mathrm{~mL}$ of $\mathrm{HF}$ and heated in an electric oven at $190^{\circ} \mathrm{C}$ for at least $24 \mathrm{hrs}$. After evaporation at $150^{\circ} \mathrm{C}$, the residue was dissolved in $1 \mathrm{~mL}$ of $\mathrm{HNO}_{3}$ and evaporated near dryness at $150^{\circ} \mathrm{C}$; this step was repeated twice. The final residue was digested once more by adding $2 \mathrm{~mL}$ of $\mathrm{HNO}_{3}$ and $3 \mathrm{~mL}$ of Milli-Q water and placed in the oven at $150^{\circ} \mathrm{C}$ for $30 \mathrm{hrs}$. This procedure resulted in clear solutions for the sediment samples. The total concentrations of $\mathrm{Ba}, \mathrm{Fe}$ $\mathrm{Cu}, \mathrm{Zn}, \mathrm{V}, \mathrm{Cr}, \mathrm{Co}, \mathrm{Ni}, \mathrm{As}, \mathrm{Cd}, \mathrm{Pb}$ and $\mathrm{Tl}$ were measured by inductively coupled plasma mass spectrometry (ICP-MS, Thermo X series II). The Fe concentration was measured using an inductively coupled plasma atomic emission spectrometer (ICP-AES, Optima 5300DVPerkinElmer, USA). Reagent blanks, duplicate samples, and standard reference materials (SRMs) were prepared to perform quality control checks. SRMs for China stream sediments (GSD2a, GSD-3a) and blank sample were employed to verify the accuracy of the analytical procedures.

\section{Estimation of Sediment Pollution Level}

Several indices, such as enrichment factor (EF), pollution load index (PLI) have been proposed to assess the trace element contamination level [20]. Metal Pollution Index (MPI) describes the composite effects of selected elements on water quality [25]. The MPI is calculated as the sum of the ratio of the concentrations of selected trace elements to their corresponding maximum allowable concentrations (MAC). The drinking water standards of China are used as MAC for the trace elements. The MPI was calculated as follows:

$$
M P I=\sum_{i=1}^{n} \frac{C_{i}}{(M A C)_{i}}
$$

...where $c_{i}$ represents concentration of 'ith' element; MAC is maximum allowable concentrations. The definition of different order of MPI can be found in [24, 26].

The potential ecological risk index $\left(\mathrm{R}_{\mathrm{T}}\right)$ was used to assess trace elements contamination in sediments. The enrichment factor (Eq. 3) was developed to account for the effects of terrestrial sedimentary input.

$$
R_{I}=\sum_{I}^{M} E_{r}^{i}=\sum_{I}^{M} T_{r}^{i} \times C_{r}^{i}=\sum_{I}^{M} T_{r}^{i} \times \frac{\mathrm{c}^{i}}{c_{n}^{i}}
$$

...where $T_{r}^{i}$ is the toxic-response factor, which is defined as $\mathrm{Zn}=\mathrm{Mn}=1<\mathrm{Cr}=2<\mathrm{Co}=\mathrm{Ni}=\mathrm{Cu}=\mathrm{Pb}=5<\mathrm{As}$ $=10<\mathrm{Cd}=30$ [27], $C_{r}{ }^{i}$ is the contamination factor, $c^{i}$ is the concentration of trace elements in sediments $(\mathrm{mg} / \mathrm{kg})$, and $c_{n}{ }^{i}$ is the reference value for the trace elements $(\mathrm{mg} / \mathrm{kg})$.

\section{Landscape Pattern and Statistical Analysis}

The landscape information was obtained from Landsat Operational Land Imager (OLI) in October, 2015. A supervised classification of maximum likelihood algorithm was carried out using the software of ERDAS 9.2 and ArcGIS 10.2. Landscape types were classified as agricultural land, forest land, grassland, built-up, water bodies, and bare land. The 20 sub-basin boundaries and average steepness slopes were delineated from digital elevation model (DEM) with a pixel size of $30 \mathrm{~m}$ (Fig. 1). Different spatial scales and the average slope were used to probe the relationships between landscape 
Table 1. Statistical characteristics of the trace elements concentrations in Le'an River ( $\mathrm{mg} / \mathrm{kg})$.

\begin{tabular}{|c|c|c|c|c|c|c|c|c|c|c|c|c|c|}
\hline & & V & $\mathrm{Cr}$ & $\mathrm{Fe}$ & Co & $\mathrm{Ni}$ & $\mathrm{Cu}$ & $\mathrm{Zn}$ & As & $\mathrm{Cd}$ & $\mathrm{Ba}$ & $\mathrm{Tl}$ & $\mathrm{Pb}$ \\
\hline \multirow{4}{*}{ May } & Mean & 0.800 & 0.581 & 621.87 & 0.969 & 2.345 & 11.855 & 14.762 & & 0.413 & 24.377 & 0.023 & 2.089 \\
\hline & Max & 1.651 & 1.388 & 2039.000 & 8.527 & 10.870 & 50.660 & 40.680 & & 2.190 & 81.430 & 0.069 & 4.522 \\
\hline & Min & 0.029 & 0.042 & 27.440 & 0.016 & 0.279 & 0.655 & 0.841 & & 0.001 & 0.961 & 0.001 & 0.187 \\
\hline & SD & 0.408 & 0.303 & 485.214 & 1.772 & 2.362 & 12.036 & 9.672 & & 0.483 & 20.944 & 0.017 & 1.110 \\
\hline \multirow{4}{*}{ August } & Mean & 1.215 & 0.300 & 368.180 & 0.635 & 1.537 & 8.695 & 17.349 & & 0.272 & 46.634 & 0.025 & 1.031 \\
\hline & Max & 3.304 & 0.465 & 972.700 & 4.090 & 5.124 & 27.900 & 218.600 & & 1.047 & 147.000 & 0.058 & 3.146 \\
\hline & Min & 0.286 & 0.138 & 131.200 & 0.107 & 0.614 & 1.339 & 2.244 & & 0.011 & 6.135 & 0.009 & 0.294 \\
\hline & SD & 0.877 & 0.086 & 179.143 & 0.774 & 0.894 & 7.112 & 43.212 & & 0.277 & 46.768 & 0.016 & 0.592 \\
\hline \multirow{4}{*}{ October } & Mean & 1.356 & 0.335 & 404.590 & 1.205 & 2.089 & 11.932 & 90.360 & 3.671 & 0.785 & 54.693 & 0.046 & 2.021 \\
\hline & Max & 2.697 & 0.845 & 1316.000 & 7.176 & 7.870 & 64.18 & 1826.000 & 17.260 & 5.933 & 159.300 & 0.253 & 9.411 \\
\hline & Min & 0.231 & 0.129 & 113.200 & 0.138 & 0.545 & 1.070 & 3.003 & 0.823 & 0.013 & 7.519 & 0.002 & 0.401 \\
\hline & SD & 0.788 & 0.162 & 331.351 & 1.514 & 1.830 & 13.096 & 370.031 & 4.394 & 1.544 & 41.693 & 0.065 & 2.313 \\
\hline \multirow{4}{*}{ December } & Mean & 1.352 & 0.651 & 474.260 & 1.720 & 2.910 & 11.408 & 73.578 & 3.137 & 2.944 & 55.258 & 0.054 & 4.944 \\
\hline & Max & 3.789 & 1.383 & 2035.000 & 4.288 & 5.124 & 36.010 & 423.200 & 14.740 & 24.200 & 132.700 & 0.202 & 13.770 \\
\hline & Min & 0.257 & 0.372 & 109.400 & 0.106 & 0.461 & 0.958 & 3.070 & 0.401 & 0.009 & 7.833 & 0.010 & 1.179 \\
\hline & SD & 1.013 & 0.215 & 378.666 & 1.108 & 1.276 & 9.802 & 121.387 & 3.653 & 6.440 & 37.420 & 0.055 & 2.896 \\
\hline
\end{tabular}

SD: standard deviation

types and concentrations of trace elements. The buffer zones include radii of 0-200 m, 300-500 $\mathrm{m}$ and $500-1,000 \mathrm{~m}$ between the main stream and its tributaries (Fig. 2). The different slope steepness was derived as $0-5^{\circ}, 6-10^{\circ}, 11-15^{\circ}, 16-20^{\circ}$, and $21-76^{\circ}$.

The landscape in different slopes was analyzed by Pearson's Correlation Analysis to estimate relationship between landscape percentage and trace element contents. Kolmogorov-Smirnov tests (K-S test) are executed to examine the data distribution. Correlations between element concentration and landscape percentages were tested through Pearson's coefficient, by setting the statistical significance $\mathrm{p}<0.05$. Multivariate analysis was carried out using hierarchical agglomerative cluster analysis (CA). Hierarchical agglomerative CA was performed by means of Ward's minimum variance method, using squared Euclidean distances as a measure of similarity.
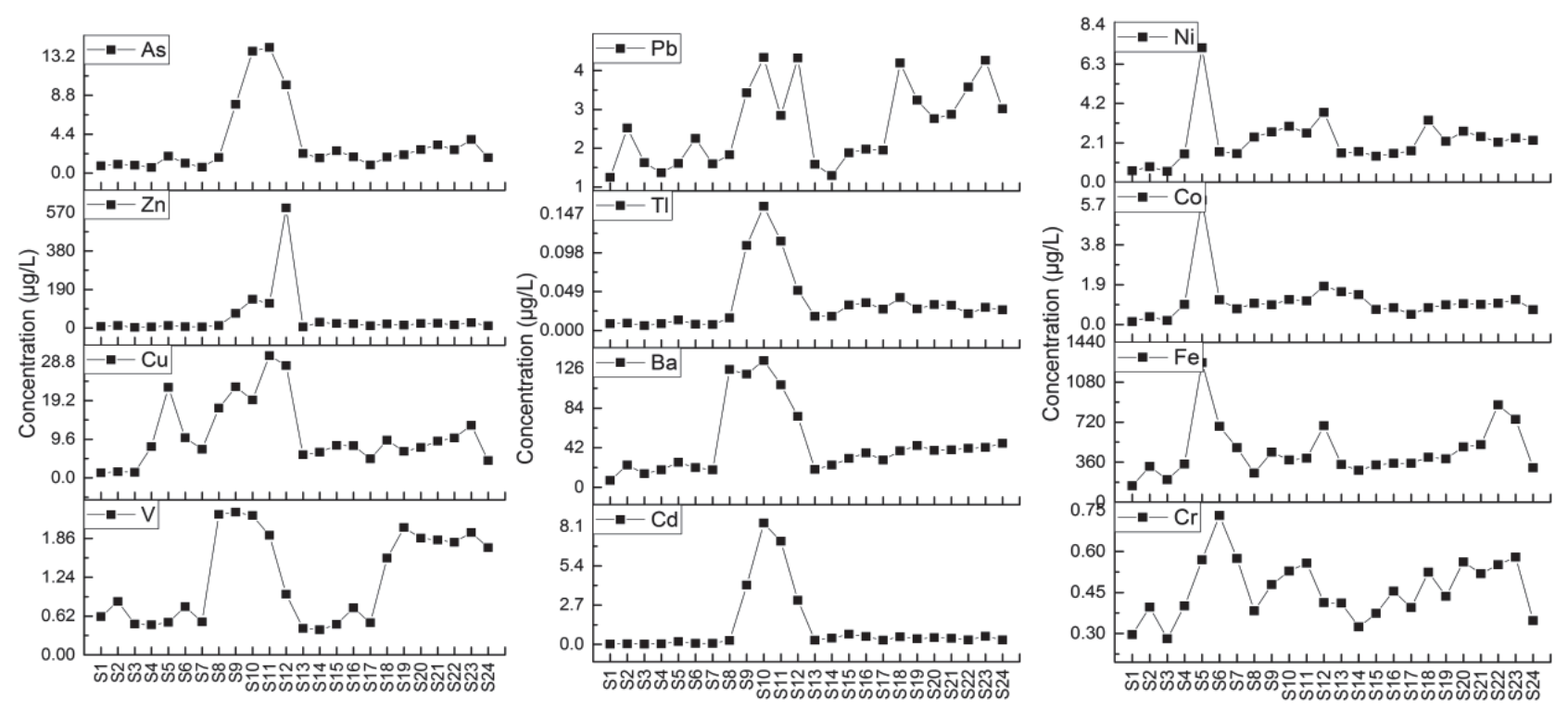

Fig. S1. Distribution of trace elements concentration of river in Le'an River Basin. 


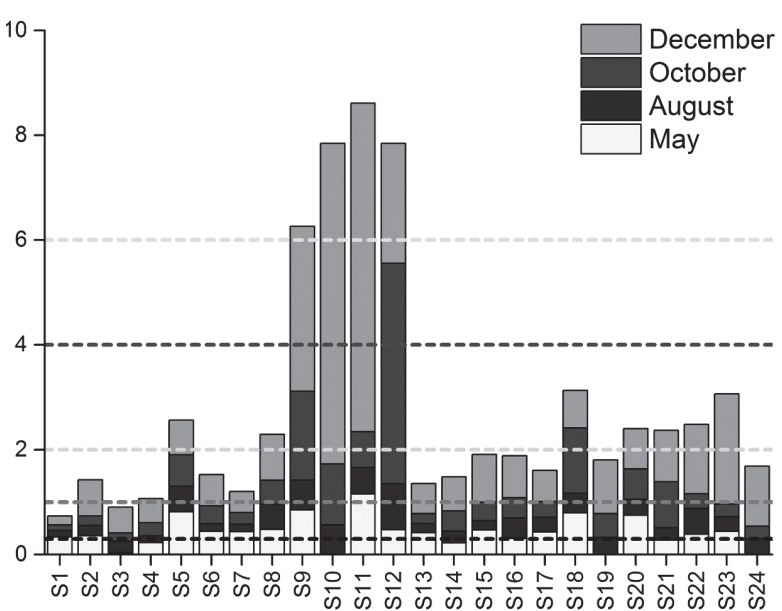

Fig. 2. MPI value of trace elements for 4 seasons in 24 sites.

\section{Results and Discussion}

Trace Element Contents in River Water and River Sediments

Trace element concentrations and distribution of surface water are illustrated in Table 1 and Fig S1, respectively. Significant seasonal differences are found in $\mathrm{V}, \mathrm{Cr}, \mathrm{Co}, \mathrm{Zn}, \mathrm{Y}, \mathrm{Cd}, \mathrm{Ba}, \mathrm{Tl}, \mathrm{Pb}$, Th and $\mathrm{U}(\mathrm{p}<0.05)$, and concentrations of trace elements in dry seasons are higher than those in wet seasons. Higher concentrations were found in mid-stream region than that in river downstream that is mainly mining areas and farmland (Fig. 1). Trace elements of $\mathrm{Cu}, \mathrm{Cd}, \mathrm{As}, \mathrm{Zn}, \mathrm{Tl}$, and $\mathrm{Ba}$ have similar spatial patterns. $\mathrm{Cr}$ and Fe contents have no obvious spatial variations.

The metal pollution index (MPI) is higher in dry seasons than that in wet seasons (Fig. 2). Water quality from site S9 to S12 is strongly affected by

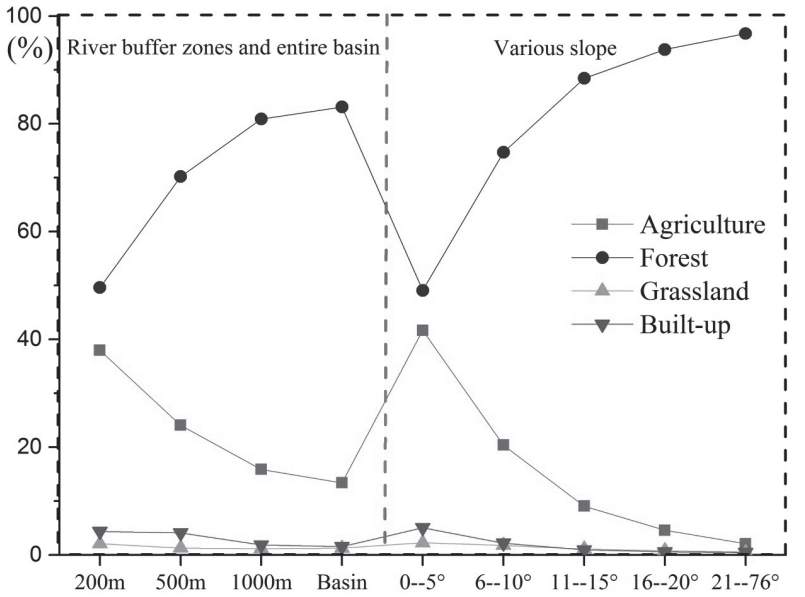

Fig. 3. The average value of different landscape types percentages in different scales and slopes.

the trace elements contamination. The surface water of all sites except S11 was clean in May. In October, water quality at S10 and S18 was slightly affected by the trace element; at S9 and S12, the MPI was moderate level, while at other sites, the MPI was low. Water quality at S15, S19, S21, S22, and S24 was slightly affected by the trace elements; water at S12 and S23 were moderately contaminated in December, and at S9, the water quality was strongly affected by anthropogenic activities. Compared to the water quality standard, at S10 and S11, the water quality seems seriously affected by the trace elements. This pattern may be caused by mining activities in dry seasons in the midstream region.

The mean concentrations of trace elements, such as $\mathrm{Cd}, \mathrm{Cu}$ and $\mathrm{Zn}$, are higher than average background values (ABV). The order of mean content divided by the local background values is listed as $\mathrm{Cd}(89.54 \mathrm{mg} / \mathrm{kg})$,
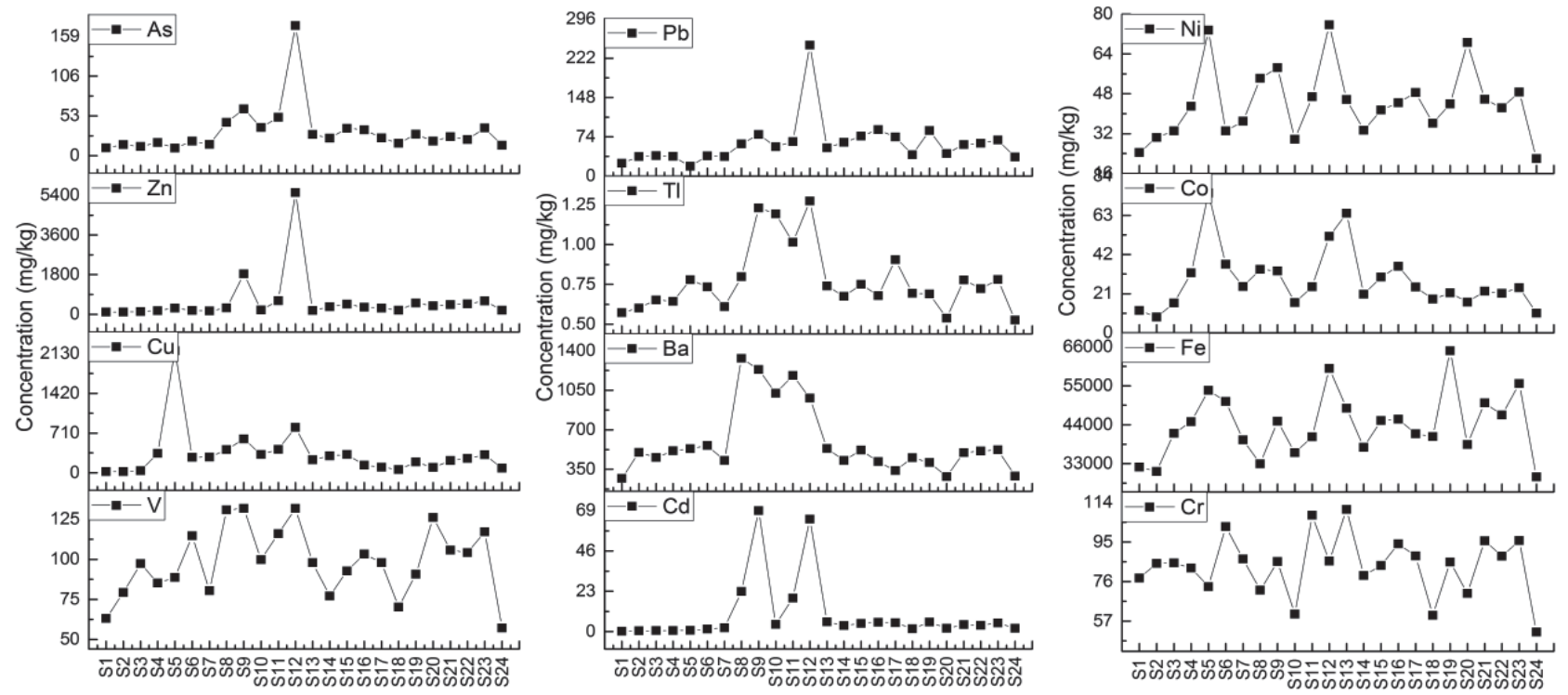

Fig.S2. Spatial distribution of river sediment trace element content in Le'an River Basin. 


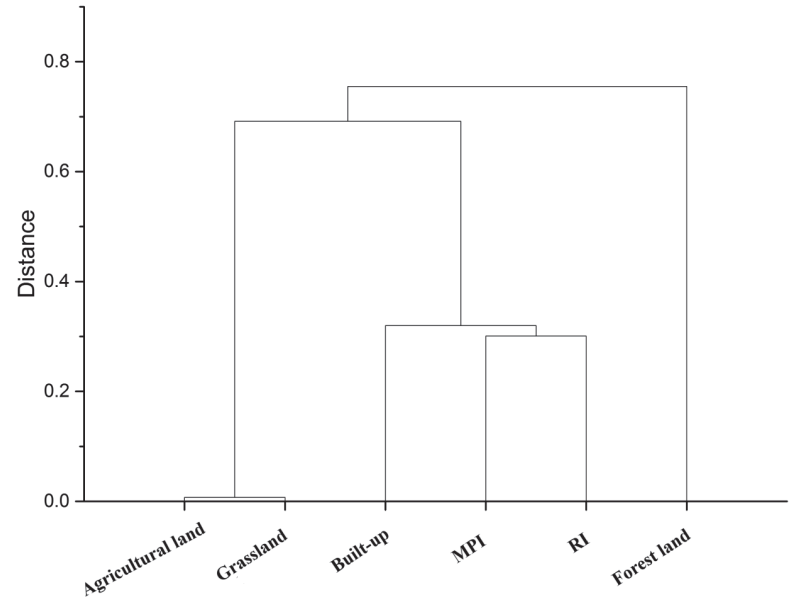

Fig. 4. Cluster analysis between land use types and trace element pollution.
$\mathrm{Cu}(16.58 \mathrm{mg} / \mathrm{kg}), \mathrm{Zn}(8.36 \mathrm{mg} / \mathrm{kg}), \mathrm{Ni}(2.34 \mathrm{mg} / \mathrm{kg})$, As $(2.17 \mathrm{mg} / \mathrm{kg}), \mathrm{Pb}(1.91 \mathrm{mg} / \mathrm{kg}), \mathrm{Cr}(1.82 \mathrm{mg} / \mathrm{kg})$, and $\mathrm{V}(0.99 \mathrm{mg} / \mathrm{kg})$. The mean contents of $\mathrm{Cr}$, $\mathrm{Ni}$ and $\mathrm{Pb}$ are below the Secondary National Standard of China, and mean contents of $\mathrm{Cu}, \mathrm{Zn}, \mathrm{Cd}$ and As displayed opposite pattern (SEPA, 1995). Higher variation coefficients $(>51 \%$ ) were observed in $\mathrm{Ba}, \mathrm{Cu}, \mathrm{Zn}, \mathrm{Co}, \mathrm{As}, \mathrm{Cd}$ and $\mathrm{Pb}$. Moderate variation coefficients $(20<\mathrm{CV}<50)$ were observed in $\mathrm{V}, \mathrm{Ni}$ and $\mathrm{Tl}$. Higher concentrations of $\mathrm{Ba}$, $\mathrm{Cu}, \mathrm{Co}, \mathrm{Zn}, \mathrm{V}, \mathrm{Ni}, \mathrm{As}, \mathrm{Tl}$ and $\mathrm{Pb}$ are found in river midstream (Fig S2).

\section{Source Apportionment of Trace Elements in River Ecosystem}

The different spatial scales of entire basin, buffer zone, and average slope were used to investigate

Table 2. Pearson's correlation coefficients between landscape types and concentrations of dissolved trace metals at the entire basin and buffer zones.

\begin{tabular}{|c|c|c|c|c|c|c|c|c|c|c|}
\hline & & AGR & FOR & GRA & BUI & & AGR & FOR & GRA & BUI \\
\hline 200 & $\mathrm{~V}$ & $0.600 * *$ & $-0.498^{*}$ & & $0.621 * *$ & $\mathrm{Zn}$ & $0.502 *$ & $-0.612 * *$ & & $0.574 * *$ \\
\hline 500 & & $0.588^{* *}$ & $-0.564 * *$ & & $0.718^{* *}$ & & $0.561 *$ & $-0.669 * *$ & & $0.576^{* *}$ \\
\hline 1000 & & $0.502 *$ & & & $0.693 * *$ & & 0.600 ** & $-0.600 * *$ & & \\
\hline Basin & & & & & $0.670^{* *}$ & & & & & $0.588^{* *}$ \\
\hline 200 & $\mathrm{Cr}$ & & & & & As & $0.543^{*}$ & $-0.680^{* *}$ & & $0.890^{* *}$ \\
\hline 500 & & & & & & & $0.650^{* *}$ & $-0.743 * *$ & & $0.835^{* *}$ \\
\hline 1000 & & & & & & & $0.677^{* *}$ & $-0.656^{* *}$ & & $0.663^{* *}$ \\
\hline Basin & & & & & & & & & & $0.856^{* *}$ \\
\hline 200 & $\mathrm{Fe}$ & & & & & $\mathrm{Cd}$ & $0.641^{* *}$ & $-0.734 * *$ & & $0.896^{* *}$ \\
\hline 500 & & & & & & & $0.689^{* *}$ & $-0.764 * *$ & & $0.872 * *$ \\
\hline 1000 & & & & & & & $0.725^{* *}$ & $-0.723 * *$ & & $0.702 * *$ \\
\hline Basin & & & & & & & & & & $0.866^{* *}$ \\
\hline 200 & Co & & & & & $\mathrm{Ba}$ & $0.803 * *$ & $-0.737 * *$ & & $0.756^{* *}$ \\
\hline 500 & & & & & & & $0.786^{* *}$ & $-0.809 * *$ & & $0.779 * *$ \\
\hline 1000 & & & & & & & $0.732 * *$ & $-0.692 * *$ & & $0.556^{*}$ \\
\hline Basin & & & & & & & & & & $0.723^{* *}$ \\
\hline 200 & $\mathrm{Ni}$ & & & & & $\mathrm{Tl}$ & $0.674 * *$ & $-0.751 * *$ & & $0.898^{* *}$ \\
\hline 500 & & & & & & & $0.712 * *$ & $-0.777 * *$ & & $0.876^{* *}$ \\
\hline 1000 & & & & & & & $0.744 * *$ & $-0.733^{* *}$ & & $0.710^{* *}$ \\
\hline Basin & & & & & & & & & & $0.879^{* *}$ \\
\hline 200 & $\mathrm{Cu}$ & & $-0.445^{*}$ & & $0.732 * *$ & $\mathrm{~Pb}$ & $0.570^{* *}$ & $-0.726^{* *}$ & & $0.687^{* *}$ \\
\hline 500 & & $0.471^{*}$ & $-0.556^{*}$ & & $0.704 * *$ & & $0.680^{* *}$ & $-0.762 * *$ & & $0.737 * *$ \\
\hline 1000 & & & & & $0.630^{* *}$ & & $0.723^{* *}$ & $-0.696^{* *}$ & & $0.632 * *$ \\
\hline Basin & & & & & $0.737 * *$ & & & & & $0.704 * *$ \\
\hline
\end{tabular}

$* \mathrm{P}<0.05$ (correlation is significant); $\quad * * \mathrm{P}<0.01$ (correlation is significant) AGR: agricultural land; FOR: forest land; GRA: grassland; BUI: built-up 
Table S1. Pearson's correlation coefficients between landscape types and sediment trace elements content at the entire basin and buffer zones.

\begin{tabular}{|c|c|c|c|c|c|c|c|c|c|c|}
\hline (m) & & AGR & FOR & GRA & BUI & & AGR & FOR & GRA & BUI \\
\hline 200 & $\mathrm{~V}$ & $0.521^{*}$ & & & $0.697 * *$ & $\mathrm{Zn}$ & $0.713 * *$ & $-0.588^{*}$ & & $0.815^{* *}$ \\
\hline 500 & & $0.530^{*}$ & $-0.55^{*}$ & & $0.736^{* *}$ & & $0.690 * *$ & $-0.68 * *$ & & $0.837^{* *}$ \\
\hline 1000 & & & & & & & $0.551^{*}$ & $-0.51^{*}$ & & $0.587^{*}$ \\
\hline Basin & & & & & $0.749 * *$ & & & & & $0.873 * *$ \\
\hline 200 & $\mathrm{Cr}$ & & & & & As & & & & $0.71 * *$ \\
\hline 500 & & & & & & & & $-0.454^{*}$ & & $0.727^{* *}$ \\
\hline \multicolumn{11}{|l|}{1000} \\
\hline Basin & & & & & & & & & & $0.771 * *$ \\
\hline 200 & $\mathrm{Fe}$ & & & & & $\mathrm{Cd}$ & $0.609 * *$ & $-0.543^{*}$ & & $0.723 * *$ \\
\hline 500 & & & & & & & $0.621 * *$ & $-0.666^{* *}$ & & $0.736^{* *}$ \\
\hline 1000 & & & & & & & $0.451 *$ & & & \\
\hline Basin & & & & & & & & & & $0.785^{* *}$ \\
\hline 200 & Co & & & & & $\mathrm{Ba}$ & & & $-0.662 * *$ & \\
\hline \multicolumn{11}{|l|}{500} \\
\hline 1000 & & & & & & & & & $-0.543 *$ & \\
\hline \multicolumn{11}{|l|}{ Basin } \\
\hline 200 & $\mathrm{Ni}$ & & & & $0.574 *$ & $\mathrm{Tl}$ & & & & $0.587^{*}$ \\
\hline 500 & & & $-0.47^{*}$ & & $0.591 *$ & & & $-0.471^{*}$ & & \\
\hline \multicolumn{11}{|l|}{1000} \\
\hline Basin & & & & & $0.626^{*}$ & & & & & $0.644 *$ \\
\hline 200 & $\mathrm{Cu}$ & & & $-0.675^{* *}$ & & $\mathrm{~Pb}$ & & & & $0.701 * *$ \\
\hline 500 & & & & & & & & $-0.509^{*}$ & & $0.705^{* *}$ \\
\hline \multicolumn{11}{|l|}{1000} \\
\hline Basin & & & & & & & & & & $0.736^{* *}$ \\
\hline
\end{tabular}

$* \mathrm{P}<0.05$ (correlation is significant); $\quad * * \mathrm{P}<0.01$ (correlation is significant)

AGR: agricultural land; FOR: forest land; GRA: grassland; BUI: built-up

effects of landscape changes on contents of trace elements. There are substantial differences in landscape composition. For example, in the entire basin, forest land is a major landscape type followed by agricultural land, grassland, and built-up, with the percentage of $81.99 \%, 15.70 \%, 1.54 \%$, and $0.69 \%$, respectively (Fig. 3). The landscape composition evolved dramatically when the slope steepness increased from $0^{\circ}$ to $15^{\circ}$, while it did not exhibit substantial changes when the slope steepness was higher than $15^{\circ}$. The percentage of forest land and agricultural land showed an increasing trend with slope steepness and buffer radius increasing. The higher the slope steepness and buffer radius were, the higher percentage of forest land, and the lower percentage of agricultural land were. Agricultural land percentage was obviously higher than that of forest land with low slope $\left(<10^{\circ}\right)$ and buffer radius $(<500 \mathrm{~m})$.

Landscape composition affects trace element pollution of ecosystems along the river. Cluster analysis (CA) was performed, and the nearest neighbor method was applied to analyze effects of landscape types on pollutant loads. Water and sediment contamination index are represented by MPI and RI. Accordingly, a $20 \times 6$ data matrix was created for the CA where the objects had 20 sampling points and 6 variables including primary landscape types and pollutant loads (Fig. 4). The built-up percentage has the closest relationship with trace elements contamination in the Le'an River ecosystem. This indicates that trace element pollution is mainly affected by anthropogenic activities. 
Effects of Landscape Types on Trace Element Contents on Multiple Scales

Pearson's correlation analysis was conducted to analyze the relationship between landscape percentages on multiple spatial scales (entire basin, river buffer zone with average steepness slope) and trace element contents. Trace element contents exhibit significant positive correlation with the percentages of agricultural land and built-up, while significant negative correlation with those of the forestland and grassland (Table 2 and Table S1). In entire basin and river buffer zone, percentages of landscapes in river riparian showed more obvious correlations with river trace element contents than those in the entire sub-basin, especially in $0-500$ $\mathrm{m}$ river buffer zone. The correlations of percentages of agricultural land, forest land and grassland with trace element contents decreased dramatically, especially from $500 \mathrm{~m}$ radius of river buffer zone to entire subbasin. Significant positive correlation between trace

Table 3. Pearson's correlation coefficients between landscape types and concentrations of dissolved trace metals in multiple slopes.

\begin{tabular}{|c|c|c|c|c|c|c|c|c|c|c|}
\hline & & AGR & FOR & GRA & BUI & & AGR & FOR & GRA & BUI \\
\hline $0--5$ & $\mathrm{~V}$ & $0.683 * *$ & \multicolumn{2}{|c|}{$-0.576^{* *}$} & & $\mathrm{Zn}$ & $0.544^{*}$ & $-0.531 *$ & & $0.985 * *$ \\
\hline 6--10 & & $0.623 * *$ & $-0.532 *$ & & & & $0.567 * *$ & \multicolumn{2}{|c|}{$-0.611 * *$} & $0.954 * *$ \\
\hline $11--15$ & & & & & & & & & & $0.853^{* *}$ \\
\hline $16--20$ & & & & & $0.451^{*}$ & & & & & $0.741^{* *}$ \\
\hline $21--76$ & & & & & $0.583^{* *}$ & & & & & $0.622 * *$ \\
\hline $0--5$ & $\mathrm{Cr}$ & & & & & As & $0.639 * *$ & \multicolumn{2}{|c|}{$-0.614^{* *}$} & $0.638 * *$ \\
\hline 6--10 & & & & & & & $0.674 * *$ & \multicolumn{2}{|c|}{$-0.686^{* *}$} & $0.739 * *$ \\
\hline $11--15$ & & & & & & & & & & $0.857 * *$ \\
\hline $16--20$ & & & & & & & & & & $0.892 * *$ \\
\hline $21--76$ & & & & & & & & & & $0.860^{* *}$ \\
\hline $0--5$ & $\mathrm{Fe}$ & & & & & $\mathrm{Cd}$ & $0.678^{* *}$ & \multicolumn{2}{|c|}{$-0.647 * *$} & $0.474 *$ \\
\hline 6--10 & & & $-0.529 *$ & & & & $0.686^{* *}$ & \multicolumn{2}{|c|}{$-0.726^{* *}$} & $0.609 * *$ \\
\hline $11--15$ & & & $-0.498^{*}$ & & & & & $-0.451 *$ & & $0.770^{* *}$ \\
\hline $16--20$ & & & & & & & & & & $0.841 * *$ \\
\hline $21--76$ & & & $-0.466^{*}$ & & & & & & & $0.830^{* *}$ \\
\hline $0--5$ & Co & & & & & $\mathrm{Ba}$ & $0.866^{* *}$ & \multicolumn{2}{|c|}{$-0.789 * *$} & \\
\hline 6--10 & & & & & & & $0.820^{* *}$ & \multicolumn{2}{|c|}{$-0.759 * *$} & \\
\hline $11--15$ & & & & & & & & & & $0.650 * *$ \\
\hline $16--20$ & & & & & & & & & & $0.762 * *$ \\
\hline $21--76$ & & & & & & & & & & $0.892 * *$ \\
\hline $0--5$ & $\mathrm{Ni}$ & $0.573^{* *}$ & \multicolumn{2}{|c|}{$-0.636^{* *}$} & & $\mathrm{Tl}$ & $0.679 * *$ & \multicolumn{2}{|c|}{$-0.670 * *$} & \\
\hline 6--10 & & $0.626^{* *}$ & \multicolumn{2}{|c|}{$-0.660 * *$} & & & $0.699 * *$ & \multicolumn{2}{|c|}{$-0.748 * *$} & $0.487^{*}$ \\
\hline $11--15$ & & & & & & & & $-0.446^{*}$ & & $0.717 * *$ \\
\hline $16--20$ & & & & & & & & & & $0.825^{* *}$ \\
\hline $21--76$ & & & & & & & & & & $0.828^{* *}$ \\
\hline $0--5$ & $\mathrm{Cu}$ & $0.528^{*}$ & $-0.456^{*}$ & & $0.575^{* *}$ & $\mathrm{~Pb}$ & $0.617^{* *}$ & \multicolumn{2}{|c|}{$-0.674 * *$} & $0.543^{*}$ \\
\hline 6--10 & & $0.502 *$ & $-0.468^{*}$ & & $0.697 * *$ & & $0.645^{* *}$ & \multicolumn{2}{|c|}{$-0.731^{* *}$} & $0.490^{*}$ \\
\hline $11--15$ & & & & & $0.829 * *$ & & & & & $0.577 * *$ \\
\hline $16--20$ & & & & & $0.859 * *$ & & & & & $0.586^{* *}$ \\
\hline $21--76$ & & & & & $0.869 * *$ & & & & & $0.535^{*}$ \\
\hline
\end{tabular}

$* \mathrm{P}<0.05$ (correlation is significant); $\quad * * \mathrm{P}<0.01$ (correlation is significant)

AGR: agricultural land; FOR: forest land; GRA: grassland; BUI: built-up 
Table S2. Pearson's correlation coefficients between landscape types and sediment trace element content in multiple slopes.

\begin{tabular}{|c|c|c|c|c|c|c|c|c|c|c|}
\hline$\circ$ & & AGR & FOR & GRA & BUI & & AGR & FOR & GRA & BUI \\
\hline $0-5$ & $\mathrm{~V}$ & $0.618^{*}$ & $-0.556^{*}$ & & & $\mathrm{Zn}$ & $0.727 * *$ & $-0.657^{*}$ & & $0.662 * *$ \\
\hline 6--10 & & $0.578^{* *}$ & -0.456 & & & & $0.684^{* *}$ & $-0.666^{* *}$ & & \\
\hline $11--15$ & & & & & $0.626^{* *}$ & & & & & $0.613^{*}$ \\
\hline $16--20$ & & & & & $0.671^{* *}$ & & & & & $0.767 * *$ \\
\hline $21--76$ & & & & & $0.688^{* *}$ & & & & & $0.802 * *$ \\
\hline $0--5$ & $\mathrm{Cr}$ & & & & & As & $0.578^{*}$ & & & $0.719 * *$ \\
\hline 6--10 & & & & & & & & & & $0.626^{*}$ \\
\hline $11--15$ & & & & & & & & & & $0.723^{* *}$ \\
\hline $16--20$ & & & & & & & & & & $0.82 * *$ \\
\hline $21--76$ & & & & & & & & & & $0.912 * *$ \\
\hline $0--5$ & $\mathrm{Fe}$ & & & & & $\mathrm{Cd}$ & $0.689 * *$ & $-0.675^{* *}$ & & $0.701^{* *}$ \\
\hline 6--10 & & & & & & & $0.686^{* *}$ & $-0.568^{* *}$ & & $0.714^{* *}$ \\
\hline $11--15$ & & & & & & & & & & $0.824 * *$ \\
\hline $16--20$ & & & & & & & & & & $0.873 * *$ \\
\hline $21--76$ & & & & & & & & & & $0.938^{* *}$ \\
\hline $0--5$ & Co & & & & & $\mathrm{Ba}$ & & & $-0.49^{*}$ & \\
\hline 6--10 & & & & & & & & & & $0.64 *$ \\
\hline 11--15 & & & & & & & & & & $0.653^{*}$ \\
\hline $16--20$ & & & & & & & & $0.635^{*}$ & & $0.701^{* *}$ \\
\hline $21--76$ & & & & & & & & & & $0.613^{*}$ \\
\hline $0--5$ & $\mathrm{Ni}$ & & & & $0.476^{*}$ & $\mathrm{Tl}$ & & & & $0.662^{* *}$ \\
\hline 6--10 & & & & & $0.505^{*}$ & & & & & $0.692^{* *}$ \\
\hline 11--15 & & & & & $0.604 * *$ & & & & & $0.732 * *$ \\
\hline $16--20$ & & & & & $0.618 * *$ & & & & & $0.824 * *$ \\
\hline $21--76$ & & & & & $0.613 * *$ & & & & & $0.732 * *$ \\
\hline $0--5$ & $\mathrm{Cu}$ & & & $-0.527^{*}$ & & $\mathrm{~Pb}$ & $0.644^{*}$ & & & $0.631 * *$ \\
\hline 6--10 & & & & & $0.684 * *$ & & & & & \\
\hline 11--15 & & & & & $0.648 * *$ & & & & & $0.666^{* *}$ \\
\hline $16--20$ & & & & & $0.618^{*}$ & & & & & $0.785^{* *}$ \\
\hline $21--76$ & & & & & $0.724 * *$ & & & & & $0.886^{* *}$ \\
\hline
\end{tabular}

$* \mathrm{P}<0.05$ (correlation is significant); $\quad * * \mathrm{P}<0.01$ (correlation is significant)

AGR: agricultural land; FOR: forestland; GRA: grassland; BUI: built-up

element content (except $\mathrm{V}$ and $\mathrm{Zn}$ for river water and $\mathrm{Ni}, \mathrm{As}, \mathrm{Pb}$ for river sediment) and percentage of the built-up decreased from $200 \mathrm{~m}$ radius to $1,000 \mathrm{~m}$ in buffer zone. More significant correlations are revealed in entire basin than that in 500-1,000 m radius of buffer zone. The percentages of agricultural land and forest land exhibited more obvious correlation with trace element (except $\mathrm{Zn}$ ) contents in river than that in sediments.
The correlation between percentages of landscape types and trace element contents in river and sediment was analyzed by using slope steepness of landscape types and outlets for each sub-basin (Table 3 and Table S2). The percentages of agricultural land and built-up have significant positive correlation with trace element contents. While the percentages of forest land and grassland showed a negative correlation with trace element contents. The percentages of agricultural 


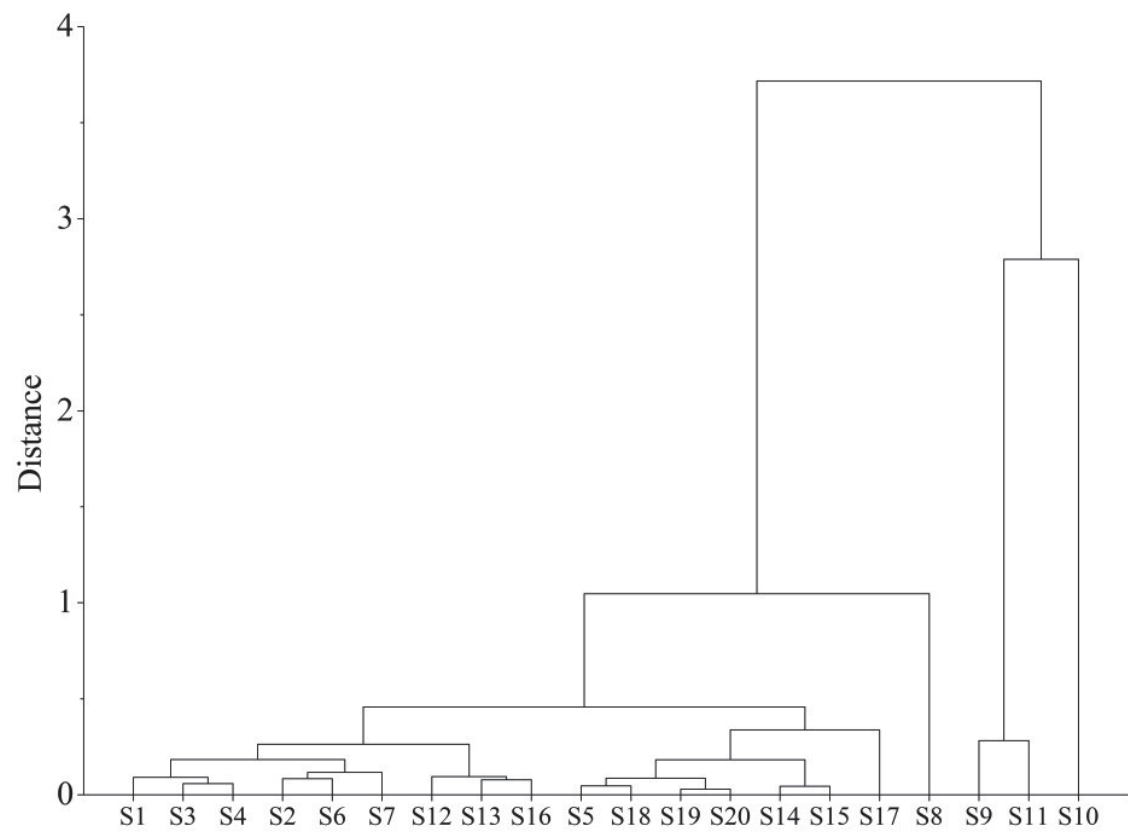

Fig. 5. Dendrogram of the sampling sites from Le'an River.

land, forest land and grassland exhibited significant correlation with trace element contents in river. When average slope steepness is higher than $10^{\circ}$, no significant correlation exists between trace element content and the percentages of agricultural land, forest land and grassland. Built-up percentages in higher steepness slope had more significant correlation with trace element contents than those in lower steepness slope. Based on landscape types in multiple spatial scales, agricultural land and built-up are major potential source places of trace elements.

Landscape composition affects trace element pollution of ecosystems along the river. Cluster analysis (CA) was performed, and the nearest neighbor method was used to analyze the effects of landscape types on pollutant loads. Cluster analysis was conducted to classify the pollution index (Fig 5). Trace element

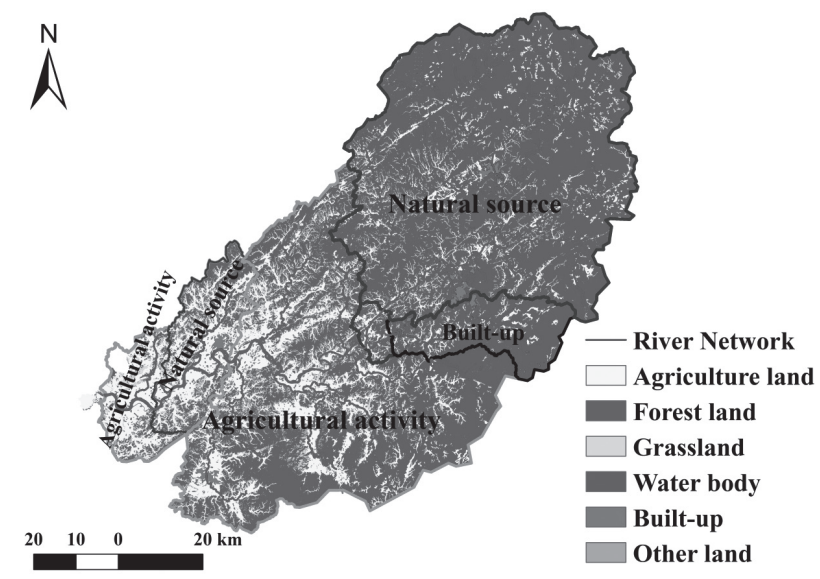

Fig. 6. Division contamination zones in Le'an River Basin. pollution degrees in river ecosystems are grouped into 4 main categories, namely, cluster 1 (sites 1-7 and 17-18), cluster 2 (sites 12-16 and 19-20), cluster 3 (sites 8 and 10), and cluster 4 (sites 9 and 11). Cluster 4 pollution is found at sites 9 and 11, implying that the pollution at these two sites was independent to that of the other sites. Based on cluster analysis, potential sources of trace element contamination zones are shown in Fig 6.

\section{Relationship between Percentages of Landscape Types and River Trace Elements Content}

Percentages of landscape types on multiple spatial scales have significant correlation with trace element contents in river. The percentages of major landscape types (agricultural land, built-up and forest land, grassland) exhibited significant positive and negative correlations with trace element contents. With the intensification of agricultural activities, fertilizers and pesticides have been widely used to improve crop yields. Anthropogenic activities have produced a huge amount of trace elements pollution in agricultural lands and aquatic ecosystems through the usage of chemical fertilizers, pesticides, and wastewater irrigation [2830]. Water erosion may facilitate the dispersion of trace elements from agricultural watershed into aquatic systems [31-32]. There is a significant negative correlation between the percentages of forestland and grassland and trace element contents in river ecosystem. Zhang et al. (2014) demonstrated that $\mathrm{Pd}, \mathrm{Cd}$ and $\mathrm{Cr}$ originated from water discharge of smelting industries, while $\mathrm{Zn}$ and $\mathrm{Cu}$ mainly originated from wastes of the copper mining industry, and Fe was related to mine tailing leaches in Daye Lake, China [33]. Vegetation, 
such as woods and grass, was the detention medium that is helpful in fixation and absorption of contaminants that flow into rivers [34]. Therefore, the percentages of forest land and grassland shows significant negative correlation with trace element contents in rivers. There is no significant correlation between the percentage of forest land and trace element contents in high slope due to that the steep area is mainly located in the transportation path of contaminants from their source places, with less frequent human activities.

Built-up is generally considered to be an important factor affecting the water quality [35]. Our results showed that the trace element content was significantly influenced by built-up percentage. Urban agglomerations of metals and metalloids can be emitted from many sources, including industry, transportation and trafficrelated activities. Urban expansion has increased impervious surface area and has changed the hydrologic cycle. These changes have led to an increase in water during rainstorms, causing environmental issues such as floods and sewerage overflows, and deteriorate water quality. Along the banks of mainstream or tributaries of the Le'an River is located a number of major cities, which became important sources of riverine trace elements. The contents of $\mathrm{Cu}, \mathrm{Zn}, \mathrm{As}, \mathrm{Cd}, \mathrm{Ba}, \mathrm{Tl}$ and $\mathrm{Pb}$ are influenced significantly by build-up land percentage. The $\mathrm{Pb}$ may come from road traffics and fossil fuel combustion. The positive correlation between built-up percentage in steep slope and contents of $\mathrm{V}$, $\mathrm{Cu}, \mathrm{Zn}, \mathrm{As}, \mathrm{Cd}, \mathrm{Ba}, \mathrm{Tl}$, and $\mathrm{Pb}$ are higher than those in low steepness slope due to the significant positive correlation increases significantly with the slope steepness increasing. The built-up land in steep slope has many mining areas and can influence trace element contents in river ecosystem. Mining activities and metal smelting are considered to be the main factors in generating hazardous trace elements [36-37].

\section{Effects of Spatial Scales on the Relationship between Landscape Percentages and Trace Element Contents}

Landscape pattern in entire sub-basin would significantly affect trace element contents in river ecosystems, but limited information is available on the spatial scale reflecting more complex relationship between landscape patterns and trace element content [38-39]. Buffer zones, designed to prevent erosion and filter out contaminants, have been widely considered as a typical landscape engineering solution for promoting water quality [40]. The establishment of riparian buffers zone has frequently been utilized to mitigate diffusive pollution in agricultural land. Landscape types on entire basin scale had little effects on the water quality. This indicates that the relationship between landscape percentages and river contamination was complex on large scale and could be influenced by other factors [41, 42]. In the Le'an River Basin, significant correlations between the percentages of agricultural land and forest land and trace elements content appear on lower-average steepness slope $\left(0-10^{\circ}\right)$ in river area. Generally, intensive agricultural activities may increase concentrations of pollutants in rivers. Appropriately $86.55 \%$ of agricultural land was located on the slopes with average steepness of $0-10^{\circ}$, which indicated that major pollution sources existed on lower steepness slopes. However, percentages of forest land and grassland in higher steepness slopes located upstream of the pollution source did not have any significant negative correlations with the dissolved trace element concentrations. The built-up and agricultural lands were mainly situated in the riverine area. Significantly, built-up land percentages exhibited weaker positive correlations with river trace element contents in lower steepness areas than those in higher steepness areas. Therefore, the concentrations of dissolved trace element were greatly affected by mining activities.

\section{Conclusions}

With the rapid industrialization and economic development in China, one-sixth of the farmland has been contaminated by trace elements. Trace elements dissolved in rivers may enter lakes under certain conditions, and deposit in lake bottom muds; hence, sediments are sinks of trace elements in aquatic environments. The relationship between landscape percentage on multiple spatial scales and river trace elements content were investigated in the Le'an River Basin, China. The results showed that concentrations of dissolved trace elements are influenced significantly by landscape percentage. Agricultural land and built-up land percentages have significant positive correlation with trace element concentrations while there is significant negative correlation between the percentages of forest land and trace element concentrations. Significant correlations existed on lower steepness slope and buffer zones of $0-500 \mathrm{~m}$. As average slope steepness increases, more significant positive correlation is shown between built-up percentage and river trace element contents. Mining activities are a major potential source because built-up land on higher steepness slope has more mining area. The built-up land in the entire sub-basin displayed higher significant relationships with trace element concentrations than that in river buffer zones. These results can be used as an indicator in identifying pollution sources of trace elements, assisting decision makers in evaluating the pollution status of the Le'an Basin and serving as a useful reference for remediation efforts in mine areas. The results provided baseline information for overall management of the Le'an river environment, and draw more attention to investigation of seasonal variability in water and sediment quality and to assessment of contaminant dynamics at the sediment-water interface. Limitation of land development activities on multiple spatial scales would enhance the river 
ecosystem health. Continuously monitoring trace element contents in sediments, water quality parameters, and individual pollution level is necessary to identify the ecosystem health status and to detect pollution sources.

\section{Acknowledgements}

This research was founded by the National Natural Science Foundation of China (No. 41861041), the Science and Technology Research Project of Jiangxi Provincial Education Department (grant no. GJJ160276), the opening Fund of Key Laboratory of Poyang Lake Wetland and Watershed Research (Jiangxi Normal University, Ministry of Education, PK2017003), China Scholarship Council (CSC No. 201708360067). Prof. Jiayi Pan at Jiangxi Normal University and Geoff Coppola have revised the English expression. Xiaoting $\mathrm{Ji}$ at Nanjing Normal University helped to revised the figures. We also like to thank the anonymous reviewers for their valuable suggestions on the original draft of the manuscript.

\section{Conflict of Interest}

The authors declare no conflict of interest.

\section{References}

1. WANG X.D., ZANG S.Y. Distribution characteristics and ecological risk assessment of toxic heavy metals and metalloid in surface water of lakes in Daqing Heilongjiang Province, China. Ecotoxicology. 23, 609, 2014.

2. ALI B.N.M., LIN C.Y., CLEOPHAS F., ABDULLAH M.H., MUSTA B. Assessment of heavy metals contamination in Mamut river sediments using sediment quality guidelines and geochemical indices. Environmental Monitor Assessment. 187,4190, 2015.

3. YE C., LI S., ZHANG Y., ZHANG Q. Assessing soil heavy metal pollution in the water-level-fluctuation zone of the Three Gorges Reservoir, China. Journal of Hazard Materials. 191 (1-3), 366, 2011.

4. HU Y.A., CHENG H.F. Application of Stochastic Models in Identification and Apportionment of Heavy Metal Pollution Sources in the Surface Soils of a Large-Scale Region. Environmental Science Technology. 47, 3752, 2013.

5. CUI B.S., ZHANG Q.J., ZHANG K.J., LIU X.H., ZHANG H.G. Analyzing trophic transfer of heavy metals for food webs in the newly-formed wetlands of the Yellow River Delta, China. Environmental Pollution. 159, 1297, 2011.

6. ZOHRA B.S., HABIB A. Assessment of heavy metal contamination levels and toxicity in sediments and fishes from the Mediterranean Sea (southern coast of Sfax, Tunisia). Environmental Science Pollution Research. 23, 13954, 2016

7. PALMA P., LEDO L., ALVARENGA P. Assessment of trace element pollution and its environmental risk to freshwater sediments influenced by anthropogenic contributions: the case study of Alqueva reservoir (Guadiana Basin). Catena. 128, 174, 2015.

8. ZHANG H., JIANG Y.H., DING M.J., XIE Z.L. Level, source identification, and risk analysis of heavy metal in surface sediments from river-lake ecosystems in the Poyang Lake, China. Environmental Science Pollution Research. 24, 21902, 2017.

9. VU C.T., LIN C., SHERN C.C., YEH G., LE V.G., TRAN H.T. Contamination, ecological risk and source apportionment of heavy metals in sediments and water of a contaminated river in Taiwan. Ecological Indicator. 82, 32, 2017.

10. YIN H.B., GAO Y.N., FAN C.X. Distribution, sources and ecological risk assessment of heavy metals in surface sediments from Lake Taihu, China. Environmental Research Letters. 6, 044012, 2011.

11. LIU A., DUODU G.O., GOONETILLEKE A., AYOKO G.A. Influence of land use configurations on river sediment pollution. Environmental Pollution. 229, 639, 2017.

12. GIRI S., QIU Z.Y. Understanding the relationship of land uses and water quality in Twenty First Century: A review. Journal of Environmental Management. 173, 41, 2016.

13. ZHAO G.J., KONDOLF G.M., MU X.M., HAN M.W., HE Z., RUBIN Z., WANG F., GAO P., SUN W.Y. Sediment yield reduction associated with land use changes and check dams in a catchment of the Loess Plateau, China. Catena. 148, 126, 2017.

14. KARSTENS S., BUCZKO U., JURASINSKI G., PETICZKA R., GLATZEL S. Impact of adjacent land use on coastal wetland sediments. Science of the Total Environment. 550, 337, 2016.

15. URIARTE M., YACKULIC C.B., LIM Y.L., ARCENAZARIO J.A. Influence of land use on water quality in a tropical landscape: a multi-scale analysis. Landscape Ecology. 26, 1151, 2011

16. HUANG Z.L., HAN L.Y., ZENG L.X., XIAO W.F., TIAN Y.W. Effects of land use patterns on stream water quality: a case study of a small-scale watershed in the Three Gorges Reservoir Area, China. Environmental Science and Pollution Research. 23, 3943, 2016.

17. SKORDAS K., KELEPERTZIS E., KOSMIDIS D., PANAGIOTAKI P., VAFIDIS D. Assessment of nutrients and heavy metals in the surface sediments of the artificially lake water reservoir Karla, Thessaly, Greece. Environmental Earth Sciences. 73, 4483. 2015.

18. CHEN H.Y., TENG Y.G., LI J., WU J., WANG J.S. Source apportionment of trace metals in river sediments: A comparison of three methods. Environmental Pollution. 211, 28, 2016.

19. HUANG S.W., JIN J.Y. Status of heavy metals in agricultural soils as affected by different patterns of land use. Environmental Monitoring and Assessment. 139, 317, 2008.

20. XIE Z.L., SUN Z.G., ZHANG H., ZHAI J. Contamination assessment of arsenic and heavy metals in a typical abandoned estuary wetland - a case study of the Yellow River Delta Natural Reserve. Environmental Monitoring and Assessment. 186,7211, 2014.

21. ASA S.C., RATH P., PANDA U.C., PARHI P.K., BRAMHA S. Application of sequential leaching, risk indices and multivariate statistics to evaluate heavy metal contamination of estuarine sediments: Dhamara Estuary, East Coast of India. Environment Monitoring and Assessment. 185, 671, 2013.

22. ZHANG Z.Y., LI J.Y., ZULPIYA M., YE Q.F. Sources identification and pollution evaluation of heavy metals in 
the surface sediments of Bortala River, Northwest China. Ecotoxicology Environmental Safety. 126, 94, 2016.

23. JIANG Y.H., XIE Z.L., ZHANG H., XIE H.Q., CAO Y. Effects of land use types on dissolved trace metal concentrations in the Le'an River Basin, China. Environmental Monitoring and Assessment. 189, 633, 2017.

24. YU S.Y., XU Z.X., WU W., ZUO D.P. Effect of land use types on stream water quality under seasonal variation and topographic characteristics in the Wei River basin, China. Ecological Indicators. 60, 202, 2016.

25. CAEIRO S., COSTA M.H., RAMOS T.B., FERNANDES F., SILVEIRA N., COIMBRA A., MEDEIROS G., PAINHO M. Assessing heavy metal contamination in Sado estuary sediments: an index analysis approach. Ecological Indicators. 5 (2), 151, 2005.

26. TAMASI G., CINI R. Heavy metals in drinking waters from Mount Amiata (Tuscany, Italy). Possible risks from arsenic for public health in the Province of Siena. Science of the Total Environment. 327(1-3), 41, 2004.

27. JIANG Y.H., XIE H.Q., ZHANG H., XIE Z.L., CAO Y. Dissolved heavy metals distribution and risk assessment in the Le'an River subjected to violent mining activities. Polish Journal of Environmental Studies. 27 (4), 1559, 2018.

28. HAKANSON L. An ecological risk index for aquatic pollution control- a sedimentological approach. Water Research. 14 (8), 975, 1980.

29. CAI L.M., XU Z.C., REN M.Z., GUO Q.W., HU X.B., HU G.C., WAN H.F., PENG P.A. Source identification of eight hazardous heavy metals in agricultural soils of Huizhou, Guangdong Province, China. Ecotoxicology and Environmental Safety. 78, 2, 2012.

30. LU A.X., WANG J.H., QIN X.Y., WANG K.Y, HAN P., ZHANG S.Z. Multivariate and geostatistical analyses of the spatial distribution and origin of heavy metals in the agricultural soils in Shunyi, Beijing, China. Science of the Total Environment. 425, 66, 2012.

31. SCHOUMANS O.F., CHARDON W.J., BECHMANN M.E., GASCUEL-ODOUX C., HOFMAN G., KRONVANG B., RUBAEK G.H., ULÉN B., DORIOZ J.M. Mitigation options to reduce phosphorus losses from the agricultural sector and improve surface water quality: A review. Science of the Total Environment. 468-469, 1255, 2014.

32. OUYANG W., WANG Y.D., LIN C.Y., HE M.C., HAO F.H., LIU H.B., ZHU W.D. Heavy metal loss from agricultural watershed to aquatic system: A scientometrics review. Science of the Total Environment. 637-638, 208, 2018.

33. CHEN H.Y., CHEN R.H., TENG Y.G., WU J. Contamination characteristics, ecological risk and source identification of trace metals in sediments of the Le'an River (China). Ecotoxicology and Environmental Safety. 125, 85, 2016.

34. ZHANG J., LI Z.H., CHEN J., WANG M., TAO R., LIU D. Assessment of heavy metal contamination status in sediments and identification of pollution source in Daye Lake, Central China. Environmental Earth Sciences. 72, 1279, 2014.

35. XU E.Q., ZHANG H.Q. Aggregating land use quantity and intensity to link water quality in upper catchment of Miyun Reservoir. Ecological Indicators. 66, 329, 2016.

36. KÄNDLER M., BLECHINGER K., SEIDLER C., PAVLU V., ŠANDA M., DOSTÁL T., KRÁSA J., VITVAR T., ŠTICH M. Impact of land use on water quality in the upper Nisa catchment in the Czech Republic and in Germany. Science of the Total Environment. 586, 1316, 2017.

37. RODRÍGUEZ L., RUIZ E., ALONSO-AZCÁRTE J., RINCÓN J. Heavy metal distribution and chemical speciation in tailings and soils around a $\mathrm{Pb}-\mathrm{Zn}$ mine in Spain. Journal of Environmental Management. 90, 1106, 2009.

38. HAMIANI O.E., KHALIL H.E., LOUNATE K., SIRGUEY C., HAFIDI M., BITTON G., SCHWARTZ C., BOULARBAH A. Toxicity assessment of garden soils in the vicinity of mining areas in Southern Morocco. Journal of Hazardous Materials. 177,755, 2010.

39. SHEN Z.Y., HOU X.S., LI W., AINI G., CHEN L., GONG Y.W. Impact of landscape pattern at multiple spatial scales on water quality: A case study in a typical urbanised watershed in China. Ecological Indicators. 48, 417, 2015.

40. ZORZAL-ALMEIDA S., SALIM A., ANDRADE M.R.M., NASCIMENTO M.N., BINI L.M., BICUDO D.C. Effects of land use and spatial processes in water and surface sediment of tropical reservoirs at local and regional scales. Science of the Total Environment. 644, 237, 2018.

41. O'DRISCOLL C., O'CONNOR M., ASAM Z.Z., de EYTO E., RODGERS M., XIAO L.W. Creation and functioning of a buffer zone in a blanket peat forested catchment. Ecological Engineering. 62, 83, 2014.

42. WANG R.Z., XU T.L., YU L.Z., ZHU J.J., LI X.Y. Effects of land use types on surface water quality across an anthropogenic disturbance gradient in the upper reach of the Hun River, Northeast China. Environmental Monitoring and Assessment. 185, 4141, 2013. 